\title{
Research on the Route to Cultivate Self-development Ability of University Students
}

\author{
Pei Zhou, Daoyun Zhang \\ School of Management, Xihua University, Chengdu, Sichuan 610039, China
}

Keywords: University Students, Self-development Ability, Cultivating Route.

\begin{abstract}
During recent years, researches on self-development abilities have been gradually emphasized by enterprises, industries or fields, which has generated certain positive influence on the social development of China. Researches on self-development ability is mainly from the perspective of development of the system, which focuses on the hematopoietic function within the system. Meanwhile, it properly attaches importance to the subsidiary role of external force. Centering on the university students, this paper makes proper researches on the route to cultivate self-development abilities of university students, with the hope of offering certain support for the well-round development of students.
\end{abstract}

\section{Introduction}

At the present stage, most Chinese universities and colleges have still taken the dominant education as the mode to cultivate talents, which attach importance to the knowledge accumulation of students and relatively ignore the cultivation of students' invisible comprehensive qualities. To a certain extent, it has weakened the inherent advantages of students in some aspect and produced certain bad influence on the cultivation of students' self-development ability. Therefore, universities and colleges must strengthen their emphasis on the cultivation of students' self-development ability. By improving the self-development abilities of students, it can promote students to obtain better development in the social life in future.

\section{Theoretical Foundation of Individual Development Ability}

Researches on individual development ability originated from the Division of Labor put forward by Adam Smith(England) in the world. Adam Smith points out that, rational division of labor can fatherly improve the specialization degree of workers in their posts and the degree of proficiency, further to promote the labor wealth created by individuals to be improved, which has correspondingly positive influence on the emancipation of labor. "Capability", the famous theory of Amartya Sen, makes corresponding illustrations about the individual abilities. He thinks that, cultivation of individuals' abilities should be considered as the final development goal during the educational process. Moreover, essence of individual development is to pursue comprehensive freedom of individuals. Researches on the individual development abilities have filtered into that theory to a certain extent. In China, researches on individual development abilities started from relevant discussions about pedagogy. In the research practice of Liu Yanhua, she considers the self-development of students as a systematic process. During the actual learning process, students should also take the initiative to plan and sort out their knowledge and skills, further to form general internalization and gradually sublimate into independence, self-regulation and self-awareness. Moreover, students can obtain the potential of sustainable development ${ }^{[1]}$. Mo Chenyu has also made proper discussions about the self-development abilities of students, who considers that 
self-development ability of students actually takes the fundamental conditions of students as the foundation, innovative and competitive. Besides, development of such ability can be affected by relevant factors, such as teachers and the society. Viewpoint of Mo Chenyu focuses on innovative ability and independent thinking ability of students, who considers that teachers and other related resources are usually subsidiary during the process of cultivating students' self-development ability. Students themselves must be crucial. Therefore, in educational practice, it should attach importance to the development of students' abilities. However, meanwhile, it still needs to pay attention to external subsidiary resources. Only by internal and external combination, cultivation of students' self-development ability can be guaranteed, further to obtain the best cultivation effect.

\section{Importance to Cultivate Self-development Ability of University Students}

The cultivation of university students' self-development ability mainly refers to cultivation of students' innovative and social competitive abilities on the premise of their own conditions. In addition, it should emphasize on playing the important role of teachers and other relevant social elements in concrete practice, further to promote cultivation of students' self-development ability to obtain the best effect. During the cultivation of university students, only by strengthening the emphasis on the cultivation of self-development ability, can it guarantee the well-round development of university students and lay a solid foundation for the growth of students in the future.

\section{Concrete Requirement for China to Promote Senior Education}

In New Age, on the basis of social educational development requirement, Chinese Ministry of Education has put forward the annual working essentials, specifically pointed out that universities and colleges should pay attention to combine the social demands with talent cultivation mode, and also make some innovations during the process of implementing senior education over university students. In addition, they should attach importance to cultivate students' ability to think independently, make innovations and practice, thus students can be cultivated into talents contributing to the socialist modernization ${ }^{[2]}$. To a certain extent, it shows that China has certain requirements for the education of Chinese university students. Consequently, universities and colleges should positively respond to the call of country and emphasize on the characteristics of school-running and educational innovations, attach importance to cultivate the self-development ability of students and cultivate students as the high-quality talents up to the hilt.

\section{Promoting Students to Learn Deeply, Strengthening the Educational Effectiveness}

After entering the senior education period, students can learn related knowledge in several ways. Knowledge acquisition scope has been consistently expanded. Moreover, the learning depth has been deepened, which has certain positive influence on the all-round growth of students. Some related investigations even show that, among the current group of college students, it is generally considered that effects of family education are inferior to the school education. In addition, effect of school education cannot be compared to that of self-learning effect. That is to say, example is better than precept. During the stage of senior education, if teachers impart knowledge into students, they should guide and promote students to discover, independently explore and solve problems with the help of adequate education. Therefore, colleges and universities should attach more importance to the cultivation of students' self-development ability, change the teaching concept and promote teachers and students to be emancipated from traditional infuse-teaching style. Moreover, through reasonable teaching guidance, universities and colleges can cultivate students' knowledge application ability and social practice ability, so as to offer corresponding guarantee for the social development of students in future.

\section{Promoting Students to Go Out of Campus and Getting Integrated into the Society}

Rules and regulations about senior education in China specifically point out that, to implement senior education over students is to improve the comprehensive qualities of students by scientific teaching 
and promote students to obtain all-round development, further to make certain contributions to the socialist modernization. However, during the period of accepting college education, university students usually receive diversified educational training, such as explanation of professional knowledge, intensified humanistic quality and physical exercise, which has generated correspondingly positive influence on all-round development of students ${ }^{[3]}$. However, during the educational process of university students, universities have placed too much emphasis on classroom teaching, but relatively neglected the cultivation of students' professional abilities after going to the society. To strengthen the self-development education of students, it can promote knowledge application ability and social practice ability of students to be correspondingly strengthened. Students' employment competitiveness can be improved to a certain extent, which is conductive for the all-round development of students. Therefore, under the education system of China, university teachers should strengthen their emphasis on cultivating self-development ability of students. By deepening their understandings about the self-development, students can feel the effectiveness of self-development abilities in the future professional life and better serve the construction of society.

\section{Route to Cultivate Self-development Ability of Contemporary University Students}

\section{Teachers should positively transform their own educational concepts and cultivate their independent ability}

In the stage of higher education, in order to cultivate students' independent ability in the educational practice and offer certain guarantee for the social life of students in future, university students can transform their educational concepts and reinforce the independent abilities of students, so as to reinforce the educational effectiveness. First of all, university teachers should transform their working concepts and specify the social status of senior education, further to correctly understand the important role of cultivating students' self-development ability in their social life in future. By consistently exploring and innovating teaching methods, it can offer more scientific guidance for students. Secondly, in the meanwhile of transforming their own educational concepts, university teachers should guide students to deeply understand the connotation of self-development ability and cultivation requirements of self-development ability. On the basis of letting students clearly understand the important role of self-development ability cultivation, teachers can guide them to independently solve those problems in life, promote their self-development ability to be correspondingly improved during consistent competition and innovation, offer corresponding guarantee for students' development in future and promote functions of senior education to be fully played $^{[4]}$.

\section{With diversified advancement, students can be promoted to form the consciousness of self-development}

On the macro level, during the process of developing the cultivation of self-development ability, universities and colleges can properly unite the government, enterprises and other related departments of higher vocational colleges, offer support for the cultivation of self-development ability, mover forward in a diversified way and create good learning environment for students and promote the cultivation to be implemented smoothly. On the micro level, university teachers should implement corresponding educational guidance with an intimate attitude, further to combine with the new educational method and try to let students deepen their understandings about the cultivation of self-development ability during the process of participating in classroom teaching. By promoting students to communicate with teachers and other students, they can gradually improve their ability of self-innovation, independence ability, communication ability and social practice ability, so as to lay a solid foundation for the cultivation of self-development ability. In addition, in educational practice, teachers should also guide and arouse students' attention to the cultivation of self-development ability by scientific teaching, guarantee students to gradually form corresponding self-development 
consciousness during the learning process, further to offer scientific guidance for their study and work and create conditions for cultivating students into talents satisfying the social demands.

\section{Teachers should make innovations of the teaching system and guide students to implement the cultivation of self-development ability}

First of all, combined with characteristics of different majors, teachers can design customized curriculum system and let students clearly understand the development orientation of the major in future and the important role of self-development ability cultivation based on the major, further to promote students to form correct understandings about the development of major and cultivation of self-development ability. In the stage of higher education, except for accepting corresponding professional guidance, students of all majors should learn corresponding elective courses combined with their own interest and development orientation in future, guarantee themselves to master skills and lay a good foundation for their development in future ${ }^{[5]}$. For instance, except for the fundamental Essentials of Economics and Western Economics, students majored in Economics should also properly learn Interpersonal Communication and Business English combined with the characteristics of major, so as to develop in an all-around way. Meanwhile, during the process of learning related theories, based on the requirements of self-development ability cultivation, teachers should also organize students to participate in simulated practice. Combined with the characteristics of the major, teachers can set up employment scenarios for students and also problems to be confronted by them in the career. By simulated practice, students can have preliminary understandings about the employment in future and know their shortcomings, so as to strengthen all skills specifically and promote the cultivation of self-development ability to be developed smoothly.

Secondly, teachers should make reasonable innovations of the teaching method. During the process of cultivating university students' self-development ability, teachers should make scientific and reasonable innovations of the teaching method, who can guarantee students to receive better educational guidance and promote them to participate in teaching practice throughout the journey. Learning interests and comprehensive learning abilities can be correspondingly reinforced, further to lay a foundation for the all-around development of students. In the aspect of concrete operation, teachers can try the brainstorming, clustering development and project teaching method, so as to implement scientific educational guidance over students. Taking the brainstorming as an example, targeted at one subject, university teachers can guide students to express their own opinions in the educational practice. Moreover, while students are publishing their opinions, teachers make no assessment. After students express their opinions, teachers make a general analysis and summary, further to lead students to find their shortcomings in answers and make proper amendments. Implementation of such a method can effectively improve their ability to analyze and judge things. Language competence and competitive consciousness of students can be correspondingly reinforced, which has certain positive influence on the cultivation of students' self-development ability.

Finally, by setting diversified evaluation system, teachers can correctly guide the cultivation of students' self-development ability by scientific evaluation. For contemporary university students, to check the learning situation and ability of themselves, the most important way is to participate in corresponding evaluation. In traditional educational practice of China, it usually applies the examination to evaluate the learning situation and learning ability of students. The comprehensiveness and science of evaluation are quite poor, which is bad for the stimulation of students' potentials and cultivation of comprehensive abilities. Therefore, in the new area, based on the requirement of cultivating students' self-development ability, teachers can integrate the examination paper, simulated operation and practice with each other, make comprehensive inspections on the learning situation and abilities of students by qualitative evaluation and quantitative evaluation. Moreover, combined with the evaluation result, teachers can put forward scientific guidance of students' self-development ability cultivation, so as to promote the work to get better effects. Only by this way, can students master certain fundamental theoretical knowledge during the process of receiving higher education and practice, dare to make bold innovations, thus 
their practical ability and employment competition ability can be dominantly improved, which is conductive for the better development of students in future.

\section{Conclusion}

Currently, in the stage of higher education in China, universities and colleges should combine with the social development requirements and innovate the talent cultivation mode, strengthen their emphasis on the cultivation of students' self-development ability. By reasonable educational guidance, it can improve students' innovative ability, competitive ability and social practice ability, so as to promote them to obtain all-around development. Only in this way, can universities and colleges give full play to the important role of higher education, satisfy the talent requirement of society and make corresponding contributions to the socialist modernization.

\section{Acknowledgement}

This paper is the educational reform project of Sichuan province, the title is "Exploration and Practice of Cultivating Innovative Management Abilities of Professional Accounting Talents in Local Colleges and Universities"; which is also the senior educational quality engineering project of Sichuan, the title is : "Comprehensive Pilot Reform of Accounting Major in Sichuan Province".

\section{References}

[1] Huang Ping. Researches on the Effectiveness of Vocational Guidance Based on College Students' Self-development Ability Growth, Survey of Education(EarlyPeriod),2015(3):73-74,78.

[2] Teng Jie. Explorations of Occupational Development Ability of College Students, Education Exploration,2011(1):148-149.

[3] Li Yifan, Huang Yan. Researches on the Self-identification Crisis and Reconstruction of Contemporary College Students--Investigation and Thoughts about Self-identification of College Students in Nanjing, New West (Middle Period),2015(5):53-54.

[4] Wang Xiaoxiao. Explorations of Developing Self-development Ability of University Students, Mechanical Management and Development, 2011(6):155-156.

[5] Deng Yue, Liang Wei. Influence of University Education on Cultivating Self-development Ability of University Students and Mechanism, The Guide of Science \& Education, 2015(25):1-2. 